\section{How old is}

\section{'Boxgrove man'?}

SIR - Roberts et al. ${ }^{1}$ concluded that the human tibia discovered at Amey's Eartham pit, near Boxgrove, Sussex, UK, is between 524,000 and 478,000 years old (oxygen isotope stage 13), older than the Anglian ice-age of stage 12 (ref. 1). This conclusion is based on 'correlative mammalian biostratigraphy' and comparative geomorphology. But the comparison of mammalian fossils from different sites is not underpinned by any independent geochronological age estimates determined by physical-chemical means. Nor is the geomorphological argument based on the fluvial gravels of an early River Thames at Little Oakley in East Anglia, UK unequivocal ${ }^{2}$. This is not surprising because it is notoriously difficult to date individual events and their fossils in the

\begin{tabular}{llll}
\hline \multicolumn{3}{c}{ AMINO-ACID RATIOS FROM BOXGROVE FOSSIL GASTROPODS } \\
Lab No.* & Species & $\begin{array}{l}\text { D-alloisoleucine/ } \\
\text { L-isoleucine ratio }\end{array}$ & Stratigraphic unit \\
LOND 8 & Nucella lapillus & $0.265 \pm 0.013(5)$ & Top of Slindon Sands \\
LOND 501 & N. lapillus & $0.29 \pm 0.025(4)$ & Intra Slindon Sands \\
LOND 503 & L. saxatilis & $0.308 \pm 0.032(5)$ & Intra Slindon Sands \\
LOND 346 & L. saxatilis & $0.281 \pm 0.009(4)$ & Intra Slindon Sands \\
LOND 502 & N. lapillus & $0.298 \pm 0.019(9)$ & Basal boulder beach \\
\hline
\end{tabular}

*Refers to London University. The amino-acid geochronology laboratory is now in the Earth Sciences Department, University of Wales, Cardiff. Data are standardized to $L$. littore $a^{3}$ and refer to the total hydrolysate.

the Middle Pleistocene of northwest Europe because of the uncertainties associated with applicable dating methods and paucity of suitable materials for dating.

Much progress has been made in recent years using ratios of the protein amino acids in fossils to estimate the age of molluscs. Living organisms contain only L-configuration amino acids. When they die, the L-configuration amino acids convert to those of the D-configuration (racemization). This is a reversible reaction and it results in increased $\mathrm{D} / \mathrm{L}$ ratios in fossils through time until a $\mathrm{D} / \mathrm{L}$ equilibrium ratio is reached: the older the fossil, the higher its D/L ratio will be. We applied this method to estimate the age of 27 separate fragments of marine gastropod fossils, collected for us by M. B. Roberts and M. R. Bates, from the Slindon sands and Basal Beach gravel which underlie the beds in which the human tibia was discovered. Using high-performance liquid chromatography, we measured the extent of the conversion of the protein amino acid L-isoleucine to its non-diastereoisomer D-alloisoleucine (epimerization).

The mean D-alloisoleucine/L-isoleucine ratio of all the samples is 0.29 $\pm 0.025(n=27)$ (see table). This can be converted into a calendar timescale using a model that correlates amino-acid ratios, calibrated by independent age estimates, with oxygen isotope stratigraphy ${ }^{4}$. Ratios of 0.29 are correlated with oxygen isotope stage $11(423,000-362,000$ years before present ${ }^{5}$ ), and thus provide an approximate age of about 400,000 years for 'Boxgrove man' - an entire ice-age younger than the previous estimate ${ }^{1}$.

Amplification is possible by comparison of marine and non-marine amino acid data, because the epimerization rate of Littorina littorea is similar to some terrestrial molluscs (gastropods and bivalves). At the interglacial site of Swanscombe in the lower Thames valley the mean ratio of the non-marine fossil molluses is $0.3 \pm$ $0.017(n=34)$. This is also correlated with oxygen isotope stage 11 by means of a similar, but non-marine, amino acid geochronological model ${ }^{6}$, that is constrained by stratigraphical and geomorphological age relationships of other deposits throughout southern Britain. The fossiliferous Swanscombe beds lie within the Orsett Heath gravel that directly overlies the Hornchurch Till (boulder clay) of the Anglian glaciation ${ }^{2}$. Thus, the Swanscombe aminoacid ratios of 0.3 must be post-Anglian in age. Because the Anglian is correlated with oxygen isotope stage 12 (ref. 2) $(478,000-423,000$ years before present), it follows that the Swanscombe beds, and their equivalents at Boxgrove, are younger and are thus correlated with oxygen isotope stage 11 (423,000-362,000 years before present). For comparison, the standard non-marine amino acid ratio for oxygen isotope stage 13 is $0.035 \pm 0.01(n=9)$ (ref. 6). In our view, there are too many uncertainties in the various dating methods to be able to assign a definitive date for the occurrence of early hominids in the British Isles.

\section{Q. Bowen}

\section{G. A. Sykes}

Department of Earth Sciences, University of Wales,

Cardiff CF1 3YE, UK

RoBERTS REPLIES - Bowen and Sykes state that the pre-Anglian age proposed for the Boxgrove tibia is not underpinned by any geochronological age estimate determined by physical-chemical means. We applied various methods of age estimation to the sediments and the fossils contained therein at Boxgrove ${ }^{1}$, but the fact is that the range of dates obtained was so varied that we used mammalian biostratigraphy, from a European database? to construct a more accurate and testable chronological model when combined with detailed lithostratigraphic data.

Turning to the amino-acid data, Bowen and Sykes do not include in their table the two runs that were actually carried out on
GEOCHRONOLOGICAL AGE ESTIMATES FROM BOXGROVE

Thermoluminescence ${ }^{12}$

$175.3-229.4$

Electron spin resonance ${ }^{13}$

205-281

Uranium series ${ }^{14}$

$>350$

Aminostratigraphy (marine species) $303-524$ Aminostratigraphy (terrestrial species) ${ }^{8} \quad 303-339$

Age estimates are $\times 1,000$ years before present.

Littorina littorea nor the terrestial gastropod Tichia hispida. Taking the range of means for these species ${ }^{8}$ together with the data given in Bowen and Sykes' table, and then using Bowen's correlation with the oxygen isotope record ${ }^{9}$, an age spread between stages 9 and 13 is indicated. Although the ratios from amino-acid epimerization at Boxgrove may be interpreted as internally consistent, this does not mean that they are valid when applied to wider aminostratigraphic age correlations. This point is well illustrated by ratios from Waverley Wood ${ }^{9}$ which are consistently greater than those from the Cromer Forest Bed, even though the latter site contains the ancestral form in the lineage of the water vole ${ }^{10}$ to that found at Waverley Wood.

Bowen and Sykes have still not addressed the chronologically important taxonomic differences between the Boxgrove mammalian fauna and the faunas from other sites, such as Barnham ${ }^{11}$, that they have dated to OIS 11 . There is consensus among many Quaternary researchers in Europe ${ }^{2}$ that Boxgrove cannot be the same age as the Swanscombe interglacial stage and must. therefore, as advocated in our Letter ${ }^{1}$, date from the end of the Cromerian complex. (Details of references supporting our proposed chronology are available from M. B. R. on request.)

\section{B. Roberts}

Institute of Archaeology,

University College,

London WC1H OPY, UK

1. Roberts, M.B. et al. Nature 369. 31.1-313 (1994).

2. Bridgland, D.R. Quaternary of the Thames, (Joint Nature Conservation Committee, Chapman and Hall, London, 1994).

3. Bowen, D.O. et al. Quat.Sci.Rev. 4, 279-318(1985).

4. Bowen, D.O. \& Sykes, G.A. Phil.Trans.R.Soc.Lond. B318, 619-635 (1988).

5. Imbrie, J. et al. in Milankovich and Climate Part 1 (eds Berger, A.L. et al.) 269-305 (Reidel, Dordrecht, 1984).

6. Bowen, D.Q. et al. Nature 340, 49-51 (1989).

7. van Kolfschoten, T. Medelingen Rijks Geologische Dienst 43-3, 1-69 (1990).

8. Bowen, D. Q. \& Sykes, G. A in The Middle Pleistocene Site at Boxgrove, West Sussex, UK (eds Roberts M. B. \& Parfitt S. A.) (English Heritage Monograph Series, London, in the press).

9. Bowen, D. Q. in Central East Anglia and the Fen Basin (eds Lewis S. G. et al.) 21-24 (Quaternary Research Association, London, 1991)

10. Currant, A. P. in Shotton et al. J. Quat. Sci. 8, 293-325 (1993).

11. Ashton, N. M. et al. J. Geol. Soc. 151, 599-605 (1994).

12. Parks, D. A. \& Rendall, H. M. J. Quat. Sci. 7, 99-107 (1992).

13. Grün, R. in The Middle Pleistocene Site at Boxgrove, West Sussex, UK (eds Roberts M. B. \& Parfitt S. A.) (English Heritage Monograph Series, London, in the press)

14. Rae, A. M. in The Middle Pleistocene Site at Boxgrove, West Sussex, UK (eds Roberts M. B. \& Parfitt S. A.) (English Heritage Monograph Series, London, in the press) 